\title{
OPTIONING AGRICULTURAL WATER RIGHTS FOR URBAN WATER SUPPLIES DURING DROUGHT
}

Ari M. Michelsen

Journal Article
Robert A. Young

1993

WWRC-93-15

In

American Journal of Agricultural Economics

Ari M. Michelsen

Department of Agricultural Economics and

Wyoming Water Resources Center

University of Wyoming

Laramie, Wyoming

Robert A. Young

Department of Agricultural

and

Resource Economics

Colorado State Univeristy

Fort Collins, Colorado 


\title{
Optioning Agricultural Water Rights for Urban Water Supplies During Drought
}

\author{
Ari M. Michelsen and Robert A. Young
}

\begin{abstract}
Option contracts for temporary use of irrigation water rights are evaluated as a less-expensive institutional arrangement for providing drought insurance for urban water agencies. Desirable option contract provisions are suggested and a framework for evaluating the economic benefits of water supply options is proposed. An integrated analytical system simulating the hydrologic, institutional, and economic relationships for a case study area in northeast Colorado is developed to evaluate the economic feasibility of water supply option contracts. Estimated present value benefits and sensitivity analyses indicate that dry year water options are economically viable over a considerable range of conditions.
\end{abstract}

Key words: droughts, economic evaluation, irrigation water, option contracts, simulation models, water markets, water rights.

Preparation for periods of drought is an important problem for urban water service agencies in the southwestern United States, as illustrated by the recent experience with a severe, multi-year drought in California and elsewhere in the region. Even under normal weather conditions, rapidly growing populations, increasing incomes, expanding industries plus increasing demands for environmental purposes (such as instream flow augmentation and fish and wildlife habitat) are bringing pressure on local water supplies. Municipal water suppliers have dealt with drought by conventional water storage and conveyance projects. However, these latter efforts must draw on more distant and typically more capital, energy and environmentally expensive sites.

Ari M. Michelsen is associate professor, Department of Agricultural Economics and Associate Director, Wyoming Water Resources Center, University of Wyoming, and Robert A. Young is professor emeritus , Department of Agricultural and Resource Economics, Colorado State University.

This work was supported by a cooperative agreement between the U.S.D.A. Economic Research Service and the Colorado State University Agricultural Experiment Station. The authors wish to thank James F. Booker and Edward Sparling for their suggestions, Robert Stieben, North Poudre Irrigation Company and Andrew Pineda and Dennis Bode, City of Fort Collins for their generous cooperation and assistance and journal referees for their helpful comments.

Review coordinated by Richard Adams.
Agriculture remains the dominant water user in the southwestern region, accounting for more than $80 \%$ of water consumption, but much of this water yields relatively low economic returns (Gibbons). Because the marginal foregone benefits of transferring agricultural water rights are often less than the cost of new construction projects, attention is being directed to non-structural approaches, such as market transfers of agricultural water rights (Howe, Schurmeier, and Shaw). However, outright purchases of senior water rights for drought protection may impose unwanted costs on the economies of local communities relying on irrigated agriculture (Young), and may not be the least expensive solution.

A fairly extensive literature has emerged on rural to urban water rights transfers. Saliba and Bush cataloged numerous actual recorded transfers in the southwestern states, reporting origins, destinations and where available, quantities and prices. The National Research Council recently studied cases of water transfers in seven western areas, and documented motivations, process used and adverse impacts on third parties. Citations in that report provide an extensive review of literature on institutional aspects of water marketing. Analytic studies of the economic potential for marketing irrigation water include Vaux and Howitt regarding California; Houston and Whittlesey concerning hydropower in the Pacific 
northwest; Keith et al. relating to the energy sector in Utah; and Booker and Young on interstate transfers for both instream and offstream uses from the Colorado River. Howe, Lazo, and Weber reported an ex post study of direct and secondary impacts of an actual transfer in Colorado.

Our focus here is on a new approach to water marketing: "dry year options" or "water supply option contracts" (WSOC). This concept proposes temporary transfers of irrigation water to provide secure water supplies to nonagricultural users during droughts (Quinn; Gardner). The exercise of the option would transfer water to higher valued uses when needed while preserving the water for agriculture during normal water supply situations. This approach is hypothesized to be more economically efficient than alternative approaches while helping to preserve communities dependent on irrigated agriculture.

Aside from a few instances, water-option markets have not yet developed and little attention has been given to them in the academic literature. The Metropolitan Water District (MWD) of Southern California proposed buying drought options on Colorado River water from farmers in the Palo Verde Irrigation District in southeastern California. MWD's payment offer was based on estimated agricultural land rents plus a premium to hold the option. The negotiations were brief, and farmers rejected the offer, citing inadequate option payments (T.H. Quinn, personal communication, 1988). Since then, the District has entered into a more conventional agreement to rent water year by year from District farmers. The only formal economic analyses of drought-contingent water transfers, to our knowledge, address hydropower in the Pacific Northwest. Hamilton, Whittlesey, and Halvorsen measured economic impacts of interrupting irrigation in favor of hydroelectric power generation on the Snake River in Idaho and concluded that hydropower benefits of temporary irrigation water transfers would be greater than estimated foregone net farm income. McCarl and Parandvash evaluated two proposed irrigation projects in the Columbia Basin with a stochastic programming model, showing that temporarily interrupting irrigation in water short years can reduce the opportunity costs to hydropower production from further irrigation development.

This paper extends the analysis of interruptible irrigation arrangements to the case of option contracts for satisfying municipal water demands during drought. We give particular con- sideration to the conditions necessary for establishing a drought option agreement and to the characteristics of an option contract that provides for both parties' interests. Because the urban buyer must find the option approach attractive, we formulate an equation for valuing water-option contracts, to determine the urban agency's willingness to pay as compared to an alternative investment. The approach is tested using a case study in northeastern Colorado. Computer simulations of hydrologic conditions provide realism to the drought analysis. For the case example, we assess the feasibility and value of agricultural-urban water-option contracts under alternative water supply, economic, and option contract scenarios, and draw some inferences for policy.

\section{Conditions Necessary for Establishing Water Supply Option Contracts}

A water supply option contract (henceforth WSOC) as defined here is a formal contract or agreement between a farmer or a group of farmers and an urban water user to transfer water temporarily from agriculture to urban use, during occasional critical drought periods such that the urban user secures a source of drought water supply. The farmer does not relinquish ownership of the water right and retains access to the water supply during normal supply situations. In financial exchange market terminology, the holder of an option contract has the right to buy the commodity or stock (in this case water) at a specified price, termed the striking or exercise price, from the seller of the option. The seller of the option is guaranteeing future delivery under specified conditions and price. In exchange for guaranteeing future delivery of the commodity at a set price, a further premium above the exercise price, called the option price, may be paid to the seller.

Proposed conditions or criteria required to establish water supply option markets were developed from review of the economic, institutional, and financial literatures (Randall; Howe, Alexander and Moses; Young; Cox and Rubinstein).

(1) The water supply must be reliable enough to provide sufficient water for the option use in drought years and plentiful enough in average years to supply the lower valued use.

(2) Property rights must be definable and transferrable for market exchange. Water laws 
and regulations in the semi-arid western states generally define water rights and permit temporary transfers or rentals of water, although some administrative or court approval is usually required for significant changes in location, timing and changes in type of use (Colby et al.). In some areas of the west, it may be difficult to define or accurately measure water rights. Where this is the case, it would be difficult to implement any type of water right transfer. As with water right purchases, the amount of water transferred must be adjusted for conveyance and field losses to protect third parties (return flow water users).

(3) Agricultural operations must be capable of being temporarily suspended. This requirement limits option contracts primarily to annual crop operations and will exclude most livestock operations, perennial crops, and orchards.

(4) Both buyer and seller must have realistic knowledge of water use values and alternative water supply costs.

(5) The probability and severity of drought (the expected frequency of exercising the option) must be able to be estimated within acceptable limits of risk for both parties.

(6) Total option contract costs, including both transaction costs of negotiating and adjudicating the temporary transfer of water, and the costs of transporting the water to the purchaser's point of intake must be less than the costs of the purchaser's next most costly water supply alternative.

The water supply option contracts proposed here have similarities to stock and commodity exchange market options and to interruptible energy supply contracts. Water supply option contracts, however, are unique in three crucial characteristics from stock, security, or commodity exchange market call options: $(i) \mathrm{A}$ water supply option is for the temporary use of a renewable resource and not for the ownership of the stock or commodity. The option buys the purchaser supply security, but water right ownership would remain with the seller. (ii) A water supply option is exercisable multiple times over the contract period. (With financial options, the contract is terminated with the exercise of the option.) And (iii), exercise of the water option is supply quantity dependent while the decision to exercise a stock or commodity option is based on market price.

$$
\begin{aligned}
P V O B & =\sum_{t=0}^{T}\left[\left(K_{t=0} \cdot r+M\right)_{t}-(E \cdot P)_{t}\right] d_{t}+\left[K_{t=0}-K_{t=0}(1+\alpha)^{T}\right] d_{t} \\
= & \text { [Cost of alternative] }- \text { [Expected exercise cost] }- \text { [Appreciation of alternative supply] }
\end{aligned}
$$

\section{Determining the Value of a Water Supply Option Contract}

We assume that the valuation of water supply option contract costs and benefits is from the perspective of urban users (municipal or industrial), because, in order for option contracts to be feasible, the purchaser must perceive benefits. The objective of the urban purchaser is to minimize the expected supply costs of meeting anticipated water demand for a drought of selected (political, economic, or hydrologic) fre-

Anticipated water supply requirements may be based on supply reliability standards, political decisions or economic justifications such as willingness to pay for supply security (Carson and Mitchell). A complete analysis of a city's drought water management policy includes demand side strategies, such as pricing policies, conservation programs or regulations to reduce supply requirements. We assume that the need for additional drought water supply is determined a priori and that a city, industry, or water manager seeks the least cost alternative to obtain additional drought water supply. Once estimates for drought water demand are established, it is the responsibility of water purveyors to secure an adequate supply to meet demand.

\section{Option Benefits: Comparing Option Costs With Purchase Costs}

The value of water supply option contracts is derived by comparing costs of an option with the costs of the most likely supply alternative (both in present value terms). Equation 1 formalizes this assertion. Option contract costs are compared with alternative water supply costs (such as purchasing water rights or building additional storage) to determine the present value benefit of an option contract (PVOB). If option contract costs are less than the alternative, the PVOB will be positive, representing the economic benefit of an option contract. If option contract costs are greater than the alternative, the PVOB will be negative, implying that an option contract is the more expensive alternative. Following convention in benefit-cost analysis, our evaluation is in real terms (inflation adjusted), so that costs, revenues and the discount rate are commensurate. quency and severity. 
where

$P V O B=$ present value of net option benefits;

$K=$ capital cost of alternative water supply;

$t=$ time in years from contract start $(t=0)$ to termination date $(t=T)$;

$K_{t=0} \cdot r=$ annual interest/opportunity cost of water supply alternative investment;

$M=$ generic term for the costs or benefits of the alternative (can include annual net maintenance costs of ownership; externalities; third party impacts; and urban supply benefits in nonoption periods);

$E=$ exercise cost of option;

$P=$ annual probability of option exercise $(0<$ $P<1$ );

$K_{T}=$ alternative cost at end of contract period; $\left[K_{t=0} \cdot(1+\alpha)^{T}\right]$ where $\alpha$ is the annual rate of cost appreciation/depreciation of the alternative supply;

$r=$ interest rate; and

$d_{t}=$ discount factor for present value, $1 /(1+$ $r)^{t}$.

The basis for each term in equation 1 is discussed below.

\section{Water Supply Alternative Costs}

The alternative supply cost to the urban user is the present value sum of the following two types of costs: $(i)$ the capital investment cost to acquire the alternative water supply (opportunity or bond interest costs plus principal) plus (ii) the annual maintenance/externality/third party cost or benefit (e.g., operation and maintenance on structures or ditch company assessment costs on water right purchases).

The capital outlay for the alternative must be spent from existing funds or borrowed. The amount of real income that could have been earned with the money used to make the water supply investment or the real interest cost on the capital borrowed to buy the right or construct the alternative source is the opportunity cost of the alternative. The capital cost $(K)$ of the water supply alternative is composed of two terms, opportunity or interest costs of investment $\left(K_{t} \cdot r\right)$ and principal/ownership cost $\left(K_{t}\right)$ where $K_{t=0}$ is the supply acquisition cost at the start of the contract. This approach allows us to develop an explicit variable for supply cost appreciation (a concern expressed to us by water managers) and to separate the principal cost for direct comparison with option contracts. (At the end of the option contract, the urban purchaser does not own the alternative supply.) Annual operations and/ or maintenance costs (denoted $M$ ) are also incurred with water supply ownership. Note that if water rights are purchased and rented back to farmers during non-exercise years, $M$ could be of opposite sign, reflecting an annual income in excess of annual outlay. $M$ can also be used to represent other costs or benefits, such as externalities or third party impacts (when quantified) or benefits to the city of increased water supply during nonoption periods. Each of the variables is discounted by the appropriate interest factor $d_{t}$ and summed to obtain the present value cost of the water supply alternative. The opportunity interest rate may reflect the existence of federal subsidy to local government borrowers.

\section{Water Supply Option Contract Costs}

The present value cost of a water-option contract is the sum of the costs to exercise the option (take the water) multiplied by the expected number of times of option exercise plus any cost appreciation/depreciation of the value of the alternative source plus any payments to the seller to hold the option (option price), each discounted to present value.

The cost of exercising the water-option contract $(E)$ during drought (transferring the water for urban use) is based on foregone benefits of the seller, that is, the price at which farmers are willing to release water supplies, and would be paid only when the option is exercised. Agricultural enterprise and water valuation models can be used as a starting point to estimate foregone benefits to the farmer. Actual.exercise payments need to be negotiated based on both party's perceptions of transfer losses and benefits. The probability of exercising the option is $(P)$, the annualized probability of needing the water for urban drought supply over the contract term.

By holding an option contract instead of investing in a new supply, the holder does not capture the value of any water right price appreciation. The appreciation cost of the alternative supply $\left(K_{t=0}-K_{t=0}(1+\alpha)^{T}\right)$ is the real change in water supply cost or water right price over the contract period, which, if negative, is an opportunity cost of holding the contract. The change in capital cost will depend on the type of supply alternative chosen. Our case study assumes the alternative is a water right purchase, but the equation is general and can accommodate other approaches such as reservoir construction. Water rights (the rights to a fixed share 
or quantity of water for perpetuity) are assumed to be a nondepreciating asset. However, the price of a water right is subject to fluctuation. The change in capital cost of other alternatives such as structural supply measures (dams, pipelines) may not be well defined or may have higher operating or maintenance costs. Structural alternatives have limited lifetimes and must be depreciated, potentially offsetting future cost increases of construction. The appreciation cost may be estimated from historic data or market forecasts. However, this will probably be one of the most difficult variables to forecast satisfactorily, in part because of varying individual expectations regarding the relevant future economic conditions.

As with commodity option contract value equations, the option value (PVOB) is the maximum economic benefit of an option contract; it is the maximum price a purchaser would be willing to pay for the option. Some of the option value must be paid to the agricultural water right owner as incentive to enter into an option contract. This payment is termed the option price and may be made either annually or as a lump sum. The remaining value is the net benefit to the holder of a water-option contract. The empirical analysis in our case study is based on the total value of the option. The option price, as in other commodity markets, needs to be negotiated between the purchaser and the seller.

\section{Proposed Option Contract Terms and Provisions}

Contract terms and provisions are important to identify and protect the rights of both parties. Energy supply contracts provide useful information in developing water-option contract provisions. While space limits preclude full discussion, suggested key provisions for water supply option contracts are listed below.

The exercise price is the cost each time (season/year) the option is exercised. This represents the payment to the farmer for the net value of foregone agricultural production. The exercise price needs to be negotiated between the city and individual farmers and be adjustable over time because of differences in water use, values, and market conditions. Advance notification that the option is to be exercised should be given to the seller for planning purposes so that certain variable production costs can be avoided. Shorter advance notice raises seller (agricultural) opportunity costs and the exercise price but reduces the likelihood of premature exercise by the purchaser.'

The option water quantity, method, and time of delivery need to be specified. A flexible quantity provision may be required because of variations in drought water allocation, but the minimum acceptable delivery should be specified. Escalator clauses can be used to adjust contract prices protecting sellers from the effects of inflation. Renegotiation clauses allow sellers and buyers to hedge against unforseen market changes by including provisions that allow the contract to be reopened for renegotiation, usually for price or quantity changes.

Right of first refusal allows the seller to retain the option of selling the water rights supporting the option contract before contract termination, but gives the option holder the right to match the offered price for the water right. This provision maintains water security for the holder while giving the seller future flexibility. A similar clause could allow replacement of the option with another irrigator's water rights. ${ }^{2}$ Long-term legal contracts usually provide for protection of the parties in the event of conditions beyond the control of either party and which may cause a breach of contract terms. Invoking such provisions (called force majeure provisions in legal terms) does not necessarily terminate a contract but may be used to remedy a temporary breach of contract. Arbitration or termination clauses provide procedures for entering and guiding arbitration of differences over contracts or specifying conditions for contract termination. In summary, option contract provisions identify buyer and seller responsibilities and specify their rights. As with all contracts, the individual provisions will need to be negotiated for mutual agreement.

\section{Case Study Assumptions}

The empirical case study evaluated the potential for using option contracts to provide economic drought water supply for Fort Collins, Colorado, from irrigated farmland in the Cache la Poudre River Basin northeast of Fort Collins. The alternative water supply assumed is the per-

\footnotetext{
'Discussions with farmers and water managers suggest that notification periods of six to nine months are needed to meet farm planning and crop production requirements as well as purchaser supply planning needs, with provisions included for penalties in the event of late notification.

${ }^{2}$ Farmers with whom we have talked were very reluctant to consider entering a contract without flexibility of this sort.
} 
manent purchase of agricultural water rights from the same basin. This area was chosen because: it is representative of agricultural areas impacted by growing urban demands for water; the water economy has reached the mature (increasing cost) phase; agricultural water rights in this area are in demand; strong concern for the preservation of agricultural communities has been indicated; and sufficient water exists for both urban and agricultural uses during normal flow years, a necessary condition for option markets. Both permanent and temporary market transfers of water are permitted by state law, provided that the absence of adverse third party impacts on other water users can be assured (MacDonnell).

We developed an integrated analytical system simulating the hydrologic, institutional, and economic relationships to provide the information necessary to evaluate water supply option feasibility. The integrated analysis consists of three parts: (i) a stochastic river flow model; (ii) a hydrologic and institutional allocation model; and (iii) an agricultural water supply offering price or valuation model. For additional details on option requirements or the analysis refer to Michelsen.

Drought Probability and Characteristics. One of the most widely applied methods of predicting drought (and flood) occurrences is a synthetic statistical approach (Fiering and Jackson). This method uses historical data on variations in water supply to predict the expected frequency and severity of drought. Predictions are often put in terms of the probability of the event occurring such as one event in every 20 years or a 1:20 probability.

The definition of drought is critical because it determines the criteria for analysis and the actions of decision makers (Wilhite and Glantz). A drought is usually defined as a year or a series of consecutive years with below average precipitation. However, river flow, rather than precipitation, was selected to identify and characterize drought for this study because river flows and storage are the sources of the municipal, industrial, and agricultural water supplies in the study area. The severity of drought is defined by the expected duration and deficit.

To estimate drought probabilities and characteristics of Cache la Poudre River basin inflows, we relied on a drought study and stochastic flow model of the Basin developed by Resource Consultants, Inc. (1986) for the city of Fort Collins. Computer-generated river flow forecasts were used to estimate the characteristics of droughts that could be expected to occur once every $10,20,50$, or 100 years. These are the same characteristics and periods used by the city in their planning analysis for drought water supplies.

An infinite number of variations in duration, annual shortage, and cumulative shortage representing these conditions are possible. For example, intense single drought year shortages impact direct river flow water rights the most, while longer duration droughts also impact reservoir supplies. Because of the extensive reservoir storage system in the Poudre basin, even an intense single year drought would have limited impact. Only droughts with longer durations and larger cumulative deficits have significant effect. Annual flows representative of each of the drought scenarios are used in the next stage of the analysis.

Hydrologic and Institutional Water Allocation Model. Cache la Poudre River flows are allocated using a hydrologic, institutional, and priority simulation model originally developed for the city to analyze the impact of water exchanges on the Cache la Poudre River (Labadie, Pineda, and Bode 1984). The model is an "outof-kilter" network flow model, which simulates river and ditch capacity and flows, storage reservoir operation, evaporation, municipal and agricultural demand, consumptive use, and return flows. The model incorporates the existing prior appropriation system in allocating water flows. The river flow data generated by the stochastic drought model is used as input for the allocation model.

The North Poudre Irrigation Company (NPIC), the case study entity, is the fourth largest irrigation company in the Cache la Poudre River Basin in terms of water deliveries and irrigated acreage. During an "average year," after deducting for seepage and other losses, 50,500 acre feet of water are delivered to approximately 600 , mostly agricultural shareholders. Tested against historical deliveries, the hydrologic model performed well. The predicted diversions to the NPIC are within $1 \%$ for average historical deliveries and are within $5 \%$ for the most extreme drought conditions.

Option Exercise Cost. A key concept in the analysis of dry-year options is the cost of exercising the option. We define the option ex- 
ercise cost as the minimum amount that must be paid to a farmer to maintain the same level of net income in the event of option exercise. This can be thought of as the "farmer's offering price" and would be site-specific, depending on the types of crops grown, precipitation, the quantity and cost of irrigation water, production costs, yields, and crop prices on the specific farms.

Our approach to defining the farmers' offering price goes beyond the conventional measure of foregone long-run returns to water. The farmer is viewed as being in a very short-run production decision context and requires compensation not only for the foregone return to water, but also for any fixed production costs that might be incurred because the water supply was temporarily relinquished and crop production ceased (Just, Hueth, and Schmitz). These additional costs include the opportunity costs of family labor and management, taxes, depreciation on durable equipment and cash overhead. Our estimated exercise cost is accordingly larger than the longrun value of water by the amount of compensation for nonwater fixed costs included in the offer. We assume the most costly situation facing farmers, one in which all crop production is suspended on acreage where water is optioned (in compliance with Colorado water law) and no alternative employment opportunities for family labor are available in the short-run. This provides the most severe test of the concept; if a lower out-of-pocket cost scenario is applicable, the farmer's offering price would be more favorable and the option more valuable.

The economic water valuation model, which is solved for a range of water supply scenarios, estimates the farmer's offering price, by a simple linear program (LP) representing irrigated farm enterprises in the NPIC service area. The model simulates water allocations to crops based on the available water supply, crop consumptive use and irrigation efficiency, production costs and expected profits. The objective function represents annual crop revenues minus forecasted out-of-pocket production costs; it thus measures required returns to the fixed resources noted in the previous paragraph. Annual crops produced in the region are corn, alfalfa hay, edible dry beans, and barley. Enterprise budgets for these crops are developed from data collected on representative farms in the area. In addition to the irrigated production activities, an activity for the production of dry land alfalfa is included because previously established irrigated alfalfa can produce some hay from just seasonal precipitation. The value of dry land alfalfa production is reflected in the value of water to the enterprise. Surface (furrow or flood) irrigation techniques are dominant. The focus is on the very short run, therefore irrigation and crop production methods are fixed. Crop switching is permitted within bounds to reflect other production constraints such as existing crop supply contracts and multi-season crop establishment. Water supply and crop irrigation requirements are adjusted for different drought water supply conditions. Agricultural water availability under varying hydrologic conditions is obtained from the results of the drought and hydrologic allocation models. Using this information, the economic linear programming model is solved to estimate water offering prices for a range of water supply and commodity price conditions (high, medium and low for each variable).

Assuming average crop prices, the estimated annual offering price of agricultural water is $\$ 85$ per acre foot. As explained above, this shortrun value is higher than a long-run annual value because of the inclusion of certain fixed costs that must be paid to farmers. As available water supplies are reduced under the most severe of drought conditions considered, the estimated offering price of agricultural water increases to $\$ 92$ per acre foot. Under the most extreme (low/high and high/low) water supply and crop price conditions, the estimated annual offering price of agricultural water ranged from a low of $\$ 39$ per acre foot to a high of $\$ 135$ per acre foot.

Water Supply Costs and Cost Appreciation. For the case study, the alternative source of supply is assumed to be outright purchase of irrigation water rights. Real water right prices have risen as growing urban water demand has absorbed irrigation water supplies in the region. Historic prices and appreciation rates of NPIC water rights (company shares) were analyzed to establish water right purchase prices and to estimate price appreciation (option opportunity costs). The recent purchase price for a NPIC water right would be about $\$ 3,500$ (1988 dollars) per share or $\$ 600$ per acre foot, but in 1961 NPIC water rights sold for only \$128 (1988 dollars) per acre foot. The long-term average rate of real price appreciation assumed in the base case of the economic analysis is $2.0 \%$ per year.

\section{Economic Feasibility: Case Study Results}

The economic feasibility of water supply options is calculated using equation 1 for base case 
conditions and for sensitivity to alternative economic, financial, and hydrologic scenarios. Base case values and assumptions for the equation parameters are as follows: option contract term is twenty years; the annual exercise probability is $0.05(1: 20)$; the option exercise cost (agricultural water offering price) is $\$ 90$ per acre foot (value for 1:20 year drought water supply, average crop prices), the initial water right purchase cost is $\$ 600$ per acre foot; water right prices are expected to appreciate $2.0 \%$ per year; water right management (share assessment) cost is $\$ 12$ per acre foot, per year; real (net of inflation) discount rate of $4.0 \%$ per year (reflecting taxfree municipal bond rates), and transactions costs and conveyance costs between the two alternatives are assumed to be equal, permitting them to be ignored.

\section{Economic Value of Water Supply Option Contracts}

The maximum option price that the city can afford to pay to a farmer to hold an option con- tract and still benefit over purchasing a water right (the net present benefit value) under the base case conditions (described above) is $\$ 295$ per acre foot of water optioned (table 1). Some negotiated portion of the total option value, (in addition to the exercise cost $E$ ) will need to be paid to the agricultural water right owner as incentive to hold an option. This premium is called the option price. The remainder is the net benefit to urban users of the water-option contract.

Table 1 shows the base case option value and illustrates its sensitivity to two key parameters, the discount rate and water right price appreciation rate. Simulated option contract values are positive and substantial over a wide range of discount and water right price appreciation rates except when there is a very low discount rate and with high water right price appreciation rates. Perhaps counter to intuition, water supply option values increase with increasing discount rates. With a higher discount rate, the opportunity cost of purchasing a water right increases while future option exercise costs and any appreciation in water right prices are more heavily discounted.

Table 1. Water Supply Option Contract Present Value Benefits: Base Case Conditions for a Twenty Year Contract and Sensitivity to Alternative Assumptions

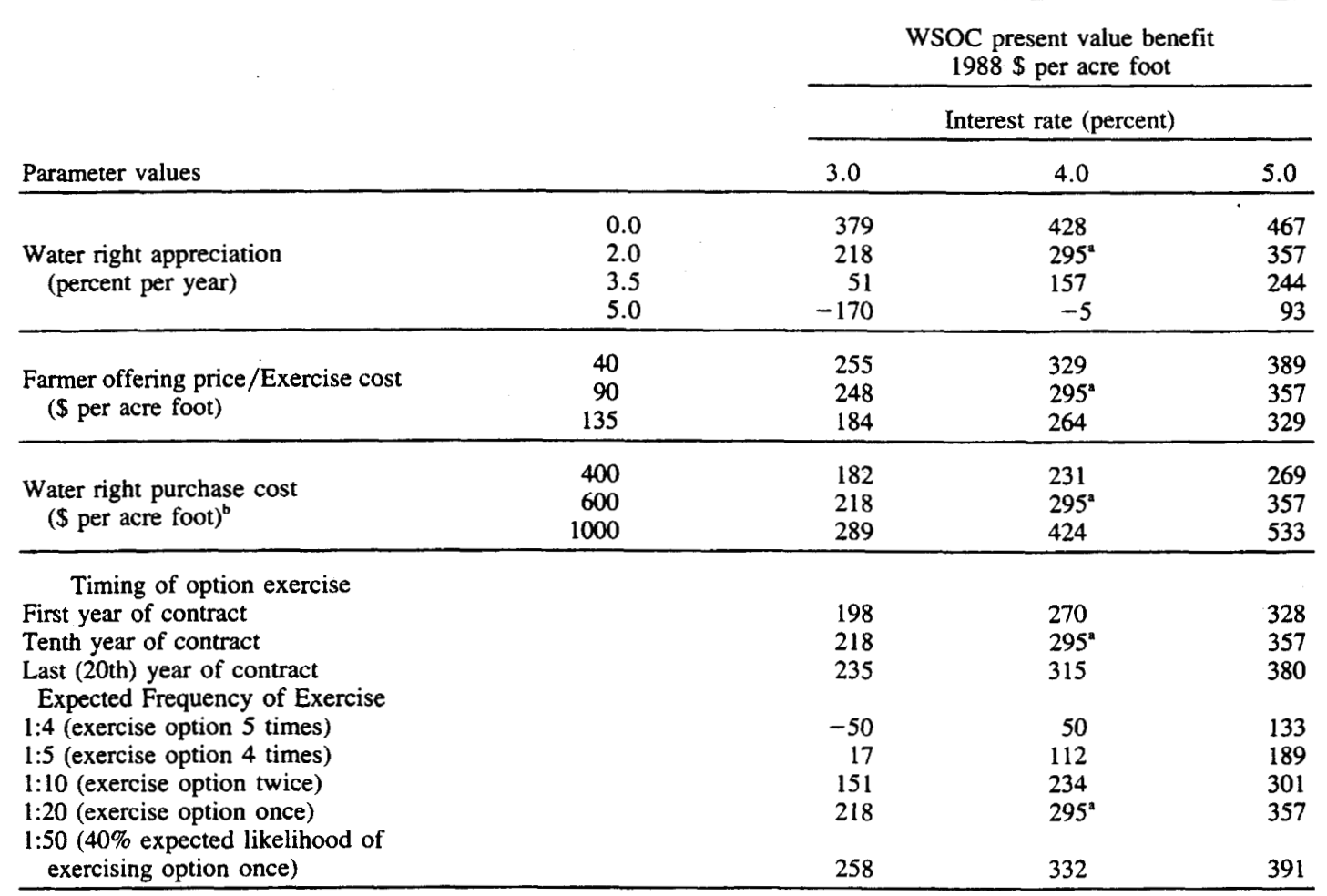

- Solution with base case parameter values.

- Cost of perpetual water right. 
As the appreciation rate of water right prices rises, option contract values decline. This occurs because the city's opportunity cost of entering into an option increases when anticipated water right prices increase more rapidly over the contract period.

Tabie 1 also displays the sensitivity of option contract benefit values to a range of alternative exercise costs (farmer offering prices), water right purchase prices and discount rates. As expected, as farmer offering prices increase (i.e., the payment for taking the water), the net benefit to the city of option contracts decreases. However, the change in benefits is less than one-to-one because the payment to exercise the option is discounted over time. Even with exercise costs of $\$ 135$ per acre foot (representing high crop prices under drought conditions or approximately $\$ 340$ per acre of crop land, option benefits are significant.

Water right purchase costs (alternative supply costs) have a large impact on option benefit values. As alternative supply costs increase, the economic benefits (avoided opportunity costs) of option contracts increase.

Timing of option exercise, whether needed in the first, tenth or last year of the contract, has a relatively small impact on option value.

Changes in the expected number of times the option is exercised affects the realized net benefit value of the option. However, benefit values are still substantial when the option is exercised more frequently than expected. Doubling the expected probability of option exercise to twice over the twenty-year contract period reduces the net benefit value by approximately $\$ 60$ (to \$234 per acre foot) holding other base case conditions constant. Even exercising the option four times (increasing the expected probability of exercising the option to one out of every five years) over the twenty-year contract period yields a benefit value of $\$ 112$ per acre foot. However, the more frequently the option is exercised, the lower the option benefit value.

Scarcity Scenarios. Our study area may not be representative of regions with more expensive, scarcer supplies of water. The Cache la Poudre basin exhibits a relatively small nonagricultural demand for water with irrigation accounting for nearly $95 \%$ of consumptive water use. The market for agricultural water rights in this region rests largely on anticipated agricultural water values. Moreover, a new reservoir capable of supplying water to the region was completed in the early 1980 s, adversely affecting water rights prices. However, in the metropolitan Denver region, only 60 miles away, urban water entities have been proposing water supply projects at costs exceeding $\$ 4,000$ per acre foot; as expected, irrigation water rights that can be used in the Denver area are scarce and have risen in price.

Given this environment, we analyzed several scenarios in which the alternative supply cost of water is much larger than the base case analysis. Also, in the event that water becomes more scarce, net maintenance costs of agricultural water rights might actually fall or even become negative. This is because cities would be able to lease water back to farmers at prices that would cover or even exceed the annual assessment charge.

Table 2 shows the results of the scarcity scenario calculations. We examined a range of water supply costs from $\$ 2,000$ to $\$ 4,000$ per acre foot, and annual maintenance costs of zero, $-\$ 10$; and $-\$ 20$ per acre foot (the negative cost implying a positive net return from renting water back to farmers or other nonoption year urban supply benefits). As expected, the higher alternative water cost increases the option value considerably. The present option value increases from

Table 2. Scarcity Scenario: Water Supply Option Contract Present Value Benefits for Varying Maintenance Costs and Initial Costs of the Alternative Supply ${ }^{a}$

\begin{tabular}{|c|c|c|c|c|c|}
\hline & & \multicolumn{4}{|c|}{$\begin{array}{l}\text { WSOC present value benefit } \\
1988 \$ \text { per acre foot }\end{array}$} \\
\hline & & \multicolumn{4}{|c|}{ Net annual maintenance costs ( $\$$ per acre foot) } \\
\hline & & 10 & 0 & -10 & -20 \\
\hline $\begin{array}{l}\text { Initial water supply cost } \\
\text { (water right purchase, } \\
\text { \$ per acre foot) }\end{array}$ & $\begin{array}{l}2,000 \\
3,000 \\
4,000\end{array}$ & $\begin{array}{r}718 \\
1,040 \\
1,362\end{array}$ & $\begin{array}{r}583 \\
904 \\
1,226\end{array}$ & $\begin{array}{r}447 \\
768 \\
1,090\end{array}$ & $\begin{array}{l}311 \\
633 \\
954\end{array}$ \\
\hline
\end{tabular}

a Assumes: farmers offering price $\$ 90 / \mathrm{AF}$; Discount rate $4 \%$; Cost appreciation rate $2 \%$ per annum. 
$\$ 125$ to $\$ 1,090$ per acre foot as the cost of an alternative water supply increases from $\$ 1,000$ to $\$ 4,000$ per acre foot, (in the case where a positive net rental value could be obtained by the urban owner). In the zero and positive net costs of maintenance cases, the values are even higher. However, considering the net negative maintenance cost case, the lower the net cost (i.e., the higher the rent), the lower is the value to the holder or buyer of an option.

\section{Conclusions}

Water supply option contracts have the potential to provide secure urban drought water supplies at a lower cost than water right purchases while maintaining the agricultural production base. Analysis of economic, hydrologic, and institutional criteria indicate that the fundamental conditions required to develop option contracts already exist in many areas of the semi-arid western United States. An integrated hydrologic-economic model system for a case study area in northeast Colorado is developed to estimate the economic and hydrologic factors required to calculate option values. The computed present value of water-option benefits for the case study indicates that dry year options are an economically viable approach under a wide range of economic conditions.

As is illustrated by the sensitivity analysis, the actual option benefits that would be achieved cannot be known with certainty. Water right price appreciation, option contract prices, frequency of exercise, exercise cost, and other variables to be negotiated or that are not well known introduce uncertainty in the contract value. Option contracts and alternatives may also have external or indirect benefits and costs such as secondary economic effects or environmental impacts, which were not addressed here. If quantified, these impacts may be incorporated into the equation or, if simply qualified, incorporated into the decision process. Moreover, in situations differing from our case study, for which conveyance costs (and transactions costs) of transporting water from farms to cities are significant, the net economic benefits could be seriously reduced or even vanish.

[Received June 1991; final revision received April 1993.]

\section{References}

Booker, J. F., and R. A. Young. "Modeling Intrastate and Interstate Markets for Colorado River Water Re- sources." J. Environ. Econ. and Manag. 22(November 1993) (forthcoming).

Carson, R. T., and R. C. Mitchell. "Economic Value of Reliable Water Supplies for Residential Water Users in the State Water Project Service Area." Technical Report, Metropolitan Water District of Southern California, Los Angeles, CA, 1987.

Colby, B. G., M. McGinnis, K. Rait, and R. Wahl. "Transferring Water Rights in the Western States: A Comparison of Policies and Procedures." University of Colorado Natural Resources Law Center, Boulder, CO, 1989.

Cox, J. C., and M. Rubinstein. Options Markets. New Jersey: Prentice-Hall Inc., 1985.

Fiering, M. B., and B. B. Jackson. Synthetic Streamflows. American Geophysical Union, Water Resources Monograph 1, Washington DC, 1971.

Gardner, R. L. "The Challenge of Marketing Water In the West." Paper presented at the Engineering Foundation Conference, Palm Coast, FL, March 30, 1987.

Gibbons, D. C. The Economic Value of Water. Washington D.C.: Resources for the Future, Inc., 1986.

Hamilton, J. R., N. K. Whittlesey, and P. Halverson. "Interruptible Water Markets in the Pacific Northwest." Am. J. Agr. Econ. 71(February 1989):63-75.

Houston, J. E. Jr., and N. R. Whittlesey. "Modeling Agricultural Water Markets for Hydropower in the Pacific Northwest.” West. J. Agr. Econ. 11(December 1986):221-31.

Howe, C. W., P. K. Alexander, and R. J: Moses. "The Performance of Appropriative Water Rights Systems in the Western United States During Drought." Natural Resources J. 22(April 1982):379-89.

Howe, C. W., D. R. Schurmeier, and W. D.Shaw, Jr. "Innovative Approaches to Water Allocation: The Potential for Water Markets." Water Resources Research 22(April 1986):439-45.

Howe, C. W., J. K. Lazo, and K. R. Weber. "The Economic Impacts of Agriculture to Urban Water Transfer on the Area of Origin: A Case Study of the Arkansas River Valley in Colorado." Am. J. Agr. Econ. 72(December 1990):1200-04.

Just, R. E., D. L. Hueth, and A. Schmitz. Applied Welfare Economics and Public Policy, Englewood Cliffs, New Jersey: Prentice-Hall Inc., 1982.

Keith, J. E., G. A. Martinez, D. L. Snyder, and T. F. Glover. "Energy and Agriculture in Utah: Response to Water Shortages." West. J. Agr. Econ. 14(July 1989):85-97.

Labadie, J. W., A. Pineda, and D. A. Bode. Network Analysis of Raw Water Supplies Under Complex Water Rights and Exchanges: Documentation for Program MODSIM3, Colorado Water Resources Research Institute, Colorado State University, March 1984.

McCarl, B., and G. H. Parandvash. "Irrigation Development versus Hydroelectric Generation: Can Internuptible Irrigation Play a Role?" West. J. Agr. Econ. 13(December 1988):267-76.

MacDonnell, L. J. The Water Transfer Process As A Management Option For Meeting Changing Water Demands, Natural Resources Law Center, University of Colorado, Boulder, May 1990.

Michelsen, A. M. Economics of Optioning Agricultural 
Water Rights for Urban Water Supplies During Drought, Unpublished Ph.D. dissertation, Department of Agricultural and Resource Economics, Colorado State University, Fort Collins, 1988.

Natural Research Council. Water Transfers in the West: Efficiency Equity and the Environment, Washington, DC, National Academy Press, 1992.

Quinn, T.H. "Water Exchanges and Transfers to Meet Future Water Demands in Southern California," Water Marketing: Opportunities and Challenges of a New Era. S. J. Shupe (ed). Conference Proceedings, University of Denver, School of Law, 1986.

Randall, A. "Property Entitlements and Pricing Policies for a Maturing Water Economy." Austral. J. Agr. Econ.25(December 1981):195-212.

Resource Consultants Inc. Droughts and Their Effect on the Water Supplies for the City of Fort Collins, CO. Fort Collins, July 1985.

Saliba, B. C., and D. B. Bush. Water Markets in Theory and Practice: Market Transfers, Water Values and Public Policy. Studies in Water Policy and Manage- ment No. 12, Boulder: Westview Press, 1987.

Vaux, H. J., and R. E. Howitt. "Managing Water Scarcity: An Evaluation of Interregional Transfers." Water Resources Research 20(September 1984):785-92.

Whittlesey, N. K., J. Hamilton, and P. Halverson. An Economic Study of the Potential for Water Markets in Idaho. Snake River Studies Advisory Committee, Office of the Governor, Idaho, Water Resources Research Institute, Moscow, ID, December, 1986.

Wilhite, D. A. and M.Glantz. "Understanding the Drought Phenomenon: The Role of Definitions." Planning for Drought: Toward a Reduction in Societal Vulnerability. D. A. Wilhite and W. E. Easterling, (eds.). Boulder: Westview Press, 1987, 11-27.

Young, R. A. "Why Are There So Few Transactions Among Water Users?" Amer. J. Agr. Econ. 68(December 1986):1143-51.

Young, R. A., S. L. Gray, with R. B. Held and R. S. Mack. Economic Value of Water: Concepts and Empirical Estimates. Report to the National Water Commission, 1972. 